\title{
Biofilm w przebiegu przewlekłego zapalenia zatok przynosowych. Badania morfologiczne w SEM
}

\author{
Biofilm from patients with chronic rhinosinusitis. \\ Morphological SEM studies
}

\author{
Roman Głowacki, Paweł Stręk, Katarzyna Zagórska-Świeży, Jacek Składzień, Krzysztof Oleś, \\ Karolina Hydzik-Sobocińska, Adam Miodoński
}

Katedra i Klinika Otolaryngologii Collegium Medicum UJ w Krakowie

Kierownik: prof. dr hab. n. med. J. Składzień

\begin{abstract}
Summary
Introduction. Bacterial biofilm is a three-dimensional structure made of aggregates of bacterial cells (microcolonies) and the extra cellular matrix released by them, adhering to organic and inorganic surfaces. It is estimated that 99\% of all bacteria exist in biofilms, and only $1 \%$ live in a free-floating or planktonic state at any given time. The aim of the study was to demonstrate biofilms in mucosal specimens of patients undergoing endoscopic sinus surgery for chronic rhinosinusitis and co-occurrence of such illnesses as nasal polyps, bronchial asthma, NSAIDs allergy, and aspirin-induced asthma. Material and methods. A prospective study of 25 patients suffering from chronic rhinosinusitis. All patients underwent completed a otolaryngological examination and paranasal sinus CT scans. Endoscopic surgery of nasal sinuses (ESS) was performed in all patients. The mucous membrane samples were taken from the inside of the sinus and concha bullosa. They were prepared and examined with a scanning electron microscope (SEM). The images were then compared with the available database of the biofilm images. Results. Using SEM morphologic criteria, the biofilms were identified in the studied material in nineteen patients (83\%). In four patients with chronic rhinosinusitis, no biofilms were found on the samples taken. A bacteriological examination of smears from inside of the sinus, revealed the presence of various types of bacteria. In two patients no bacteria was found in the smears. Conclusions. It is supposed that bacterial biofilms perform an essential role in the pathogenesis of chronic sinusitis. One may speculate that, the presence of biofilms in patients with chronic rhinosinusitis could induce the co-occurrence of such illnesses as nasal polyps, bronchial asthma, aspirin-induced asthma or a NSAIDs allergy. In order to evaluate better the role of biofilms in chronic rhinosinusitis, it seems justified to extend the research to a larger group of patients and a control group.
\end{abstract}

Ha sła in deks ow e : biofilm, przewlekłe zapalenie zatok przynosowych, skaningowy mikroskop elektronowy Ke y words: biofilms, rhinosinusitis, SEM

Otolaryngol Pol 2008; LXII (3): 305-310 @ 2008 by Polskie Towarzystwo Otorynolaryngologów - Chirurgów Głowy i Szyi

\section{WSTĘP}

W literaturze światowej pojawia się coraz więcej doniesień na temat wpływu biofilmów na przebieg przewlekłego zapalenia błony śluzowej górnych dróg oddechowych. W ostatniej dekadzie miał miejsce znaczny wzrost liczby badań nad przyczyną tworzenia się biofilmów, ich morfologią, niewiarygodną opornością na antybiotyki oraz właściwościami genetycznymi. Biofilmy bakteryjne identyfikowano w przypadkach przewlekłego zapalenia ucha środkowego i migdałków $[1,2]$. Coraz częściej biofilmy bakteryjne wymieniane są jako czynniki etiopatologiczne w przewlekłym zapaleniu zatok przynosowych (PZZP). Szacuje się, że biofilmy wywołują ponad $60 \%$ aktualnie leczonych infekcji. Infekcje wywołane przez biofilmy mają najczęściej charakter przewlekły, są oporne na działanie układu odpornościowego gospodarza, a także na eradykacje antybiotykami, nawet celowanymi, oraz charakteryzują się okresowymi zaostrzeniami w swym przebiegu [3].

Biofilm bakteryjny to trójwymiarowa struktura utworzona z agregatów komórek bakteryjnych (mikrokolonii) i wydzielanej przez nie macierzy pozakomórkowej, która przywiera do powierzchni zarówno organicznych, jak i nieorganicznych. Występują w nim kanały wodne oraz strefy, w których komórki są martwe, w stanie anabiozy oraz intensywnie się rozwijające. Mikrokolonie oddzielone są siecią otwartych kanalików. Przepływająca przez nie ciecz omywa każde zgrupowanie mikroorganizmów, dostarczając im substancji odżywczych i usuwając

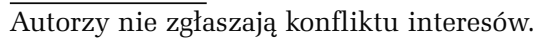


zbędne produkty przemiany materii. W ten sposób nawet głębiej położone agregacje komórek bakteryjnych mają dogodne warunki do przeżycia $[4,5]$. Macierz biofilmu składa się z polisacharydów, białek, kwasów nukleinowych oraz obumarłych populacji bakterii [6]. Szacuje się, że stanowi ok. 85\% [7] struktury biofilmu, a bakterie pozostałe 15\% [8]. Biofilmy mogą być utworzone również przez patogenne grzyby [9].

Nie ma jednej, wspólnej struktury biofilmu. Przystosowanie bakterii wewnątrz biofilmu uzależnione jest od warunków otaczającego środowiska oraz genetycznych właściwości bakterii. Bakteria może formować różne fenotypy biofilmu na różnych powierzchniach. Biofilmy pokrywające powierzchnię błon śluzowych będą się różniły pomiędzy sobą ze względu na to, że są stale poddawane działaniu systemu odpornościowego gospodarza oraz zmiennym warunkom otaczającego środowiska [10]. Przystosowanie się bakterii żyjących w biofilmie do przetrwania w trudnych warunkach wymusza ich zmiany fenotypowe. Wpływ czynników środowiska w którym bytują bakterie oraz komunikacja między ich mikrokoloniami są dwoma głównymi czynnikami, które wpływają na przekształcenie się bakterii w charakterystyczny fenotyp dla danego biofilmu [11].

Zmiany w lokalnym mikrośrodowisku wewnątrz matrix mogą przyczyniać się do powstania stanu tzw. stresu metabolicznego $[12,13]$. Jak wykazały badania eksperymentalne, wahania w stężeniu tlenu, a także różnice w stężeniu glukozy w środowisku bytowania prowadzą do naruszenia równowagi metabolicznej wewnątrz biofilmu i wywołują silną zmienność fenotypową bakterii. W rezultacie bakterie adaptują się do zaistniałego aktualnie środowiska [14, 15].

Stwierdzeniem niepodlegającym wątpliwości jest fakt, że wzorce ekspresji genów bakterii bytujących w biofilmie są całkowicie różne od takiej ekspresji bakterii występujących w formie planktonowej. Oznacza to, że geny drobnoustrojów tworzących i żyjących w biofilmie podlegają często ekspresji, co powoduje znaczne odmienności ich fenotypu w porównaniu z bakteriami formy planktonowej [11]. Tą częstą zmianą wzorca ekspresji genów można tłumaczyć istotne trudności w leczeniu chorych z PZZP oraz nawracającymi stanami zapalnymi nawet po prawidłowo przeprowadzanym leczeniu operacyjnym z przywróceniem drożności naturalnych ujść zatok.

\section{CEL}

Celem pracy było poszukiwanie biofilmów na powierzchni fragmentów błony śluzowej zatok przynosowych pacjentów poddanych operacji en-
Tabela I. Rozkład liczbowy chorych na PZZP z uwzględnieniem badania klinicznego oraz chorób wspótistniejących bez grupy kontrolnej

\begin{tabular}{l|c}
\hline Dane z wywiadu i badania klinicznego & Liczba chorych \\
\hline Polipy nosa, astma oskrzelowa i alergia na NLPZ & 3 \\
\hline Polipy nosa i astma oskrzelowa & 4 \\
\hline Polipy nosa bez wywiadu alergicznego & 4 \\
\hline Astma oskrzelowa bez obecności polipów nosa & 6 \\
\hline Brak polipów nosa i brak wywiadu alergicznego & 6 \\
\hline
\end{tabular}

doskopowej z powodu przewlekłego zapalenia zatok przynosowych.

\section{MATERIAŁ I METODY}

Do badań zakwalifikowano 25 chorych leczonych z powodu przewlekłego zapalenia zatok przynosowych (PZZP) w Klinice Otolaryngologii Collegium Medicum Uniwersytetu Jagiellońskiego w Krakowie w okresie od grudnia 2006 do grudnia 2007. Uzyskano zgodę Komisji Bioetycznej na przeprowadzenie eksperymentu medycznego. Ponadto od każdego pacjenta uzyskano indywidualną zgodę na badanie. W grupie było 18 kobiet i 7 mężczyzn w wieku od 16 do 76 lat. Grupę kontrolną stanowiło 2 pacjentów, u których stwierdzono występowanie puszkowej małżowiny środkowej. U wszystkich chorych wykonano przed zabiegiem badanie endoskopowe nosa oraz tomografię komputerową zatok przynosowych. U 11 z nich stwierdzono obecność polipów w przewodach nosowych, w 13 przypadkach PZZP współistniało $\mathrm{z}$ astmą oskrzelową. U 3 pacjentów zdiagnozowano astmę aspirynową (tab. I). Z powodu braku efektów leczenia zachowawczego (antybiotyki, leki steroidowe) pacjenci zostali zakwalifikowani do leczenia operacyjnego metodą endoskopową. U wszystkich chorych wykonano operację endoskopową zatok przynosowych (ESS). W grupie badanej obejmującej 23 chorych w trakcie zabiegu, pod kontrolą endoskopu, za pomocą kleszczyków tnących bardzo delikatnie oddzielono fragmenty błony śluzowej, aby nie naruszyć jej powierzchni. Próbki pobrano z wnętrza zatok szczękowych, klinowych, z zatok sitowych przednich i tylnych, z zachyłka czołowego, małżowiny nosowej środkowej oraz przewodu nosowego środkowego. W grupie kontrolnej liczącej 2 pacjentów pobrano próbkę błony śluzowej z bocznej ściany małżowiny puszkowej. Badano powierzchnię błony śluzowej od wewnątrz małżowiny puszkowej zakładając, że nie jest objęta procesem infekcji bakteryjnej. Średnia wielkość pobieranych wycinków wahała się w granicach $10 \mathrm{~mm}$ x $10 \mathrm{~mm}$. 
Tabela II. Wyniki wymazów bakteriologicznych pacjentów, u których stwierdzono obecność biofilmu w SEM. W 10 przypadkach wyhodowano więcej niż jeden szczep bakerii

\begin{tabular}{l|c}
\hline Typ bakterii z hodowli & Liczba chorych \\
\hline Staphylococcus aureus & 9 \\
\hline Coagulase negativ Staphylococcus & 6 \\
\hline Escherichia coli & 3 \\
\hline Morganella morganii & 2 \\
\hline Haemophilus influenzae & 2 \\
\hline Enterobacter cloacae & 2 \\
\hline Proteus mirabilis & 2 \\
\hline Klebsiella pneumoniae & 2 \\
\hline Enterococcus fecalis & 1 \\
\hline Streptococcus haemoliticus & 1 \\
\hline Enterobacter species & 1 \\
\hline Klebsiella oxytoca & 1 \\
\hline Streptococcus pneumoniae & 1 \\
\hline Propionobacterium agnes & 1 \\
\hline
\end{tabular}

Od wszystkich operowanych chorych z PZZP pobrano wymazy $\mathrm{z}$ wnętrza zatoki szczękowej do badań bakteriologicznych (hodowla). Pobrane próbki delikatnie opłukiwano solą fizjologiczną, aby nie naruszyć struktury biofilmu.

Następnie pobrane próbki zostały przygotowane do badania w skaningowym mikroskopie elektronowym (SEM). Wycinki utrwalono drogą imersji przez okres 24 godzin w temperaturze $4^{\circ} \mathrm{C}$ $\mathrm{w}$ roztworze $2,5 \%$ aldehydu glutarowego w $0,2 \mathrm{M}$ buforze kakodylowym o pH 7,4. Po dokładnym płukaniu w kilkakrotnie zmienianym $0,2 \mathrm{M}$ buforze kakodylowym $(\mathrm{pH} \mathrm{7,4)}$ preparaty powtórnie utrwalano w $2 \%$ czterotlenku osmu przez 3 godziny. Następnie próbki odwadniano we wzrastających stężeniach alkoholu etylowego i przeprowadzając przez aceton absolutny suszono w punkcie krytycznym $\mathrm{CO}_{2}$. Wysuszone preparaty montowano na stabilitach za pomocą srebrnego kleju kontaktowego i napylano złotem w sputterze JFC-1100 (Jeol, Tokyo, Japan).

Powierzchnię wycinków oglądano w SEM typu JSM-35-CF (Jeol, Tokyo, Japan) przy wartości napięcia przyspieszającego $25 \mathrm{kV}$. Wykonano około 150 zdjęć w powiększeniu od 660 do 4800 razy. Udokumentowano strukturę biofilmu pokrywającego nabłonek rzęskowy i porównano z istniejącą i dostępną bazą zdjęć biofilmów. Uzyskane mikrofotografie niezależnie od siebie oceniły 3 osoby.

Przygotowanie materiału i badanie struktury biofilmu wykonywano w Pracowni Mikroskopii Skaningowej Kliniki Otolaryngologicznej CMUJ w Krakowie.

\section{WYNIKI}

W analizowanej grupie chorych obecność biofilmu na powierzchni błony śluzowej stwierdzono u 19 pacjentów, co stanowi 83\% ogółu badanych. Identyfikacji dokonano na podstawie cech morfologicznych biofilmów przedstawionych w dostępnej literaturze, tj. trójwymiarowa struktura, obecność kolonii bakteryjnych, kanały wodne, przyleganie do nabłonka błony śluzowej. U 4 chorych na PZZP nie stwierdzono obecności biofilmu na pobranych próbkach, co stanowi 17\% ogółu badanych. U 2 pacjentów stanowiących grupę kontrolną stwierdzono obecność prawidłowego nabłonka rzęskowego wewnętrznej powierzchni concha bullosa. U wszystkich chorych z udokumentowaną obecnością biofilmu w SEM badaniem bakteriologicznym wymazów z wnętrza zatoki szczękowej stwierdzono obecność różnych rodzajów bakterii (tab. II). U jednego pacjenta z grupy badanej nie stwierdzono bakterii w wymazie oraz obecności biofilmu w SEM. W trzech przypadkach pomimo stwierdzenia obecności różnych bakterii w wymazie nie stwierdzono obecności biofilmu w SEM.

Zdjęcia przedstawiają różne etapy formowania się biofilmu od etapu przylegania do błony śluzowej, tzw. quorum sessing do etapu pełnego ukształtowania się biofilmu z charakterystycznymi wieżami, kanałami wodnymi i namnażającymi się komórkami bakterii na powierzchni matrix (ryc. 4). Obserwowane komórki bakterii przybierały kształt kulisty i eliptyczny (ryc. 1), a ich wielkość wahała się od $0,2 \mu \mathrm{m}$ do $1,2 \mu \mathrm{m}$. W jednym przypadku zidentyfikowano współwystępowanie biofilmu bakteryjnego i grzybiczego. W każdej próbce dokładnie oceniono stan morfologiczny nabłonka, zwracając uwagę na uszkodzenia rzęsek obecnych na powierzchni komórek rzęskowych (ryc. 2) oraz obecność i wielkość kulistych i eliptycznych komórek bakteryjnych. Identyfikowano komórki układu krwionośnego (erytrocyty, leukocyty), włóknik oraz względnie częstą obecność drobnego precypitatu białkowego. Szczególnie zwracano uwagę na uwidocznienie struktury biofilmu oraz położonego pod nim, najczęściej chorobowo zmienionego, nabłonka rzęskowego, pozbawionego prawidłowych rzęsek (ryc. 3). W jednym przypadku uwidoczniono różne formy planktonowe bakterii (kuliste, formujące grona i paciorki, podłużne pałeczki) oraz strzępki grzybni (ryc. 6).

W 4 przypadkach nie udało się odnaleźć struktur biofilmu na powierzchni błony śluzowej. Główną przyczyną było pokrycie powierzchni próbki warstwą skrzepu krwi, uniemożliwiającą ocenę charakterystycznej struktury nabłonka. 


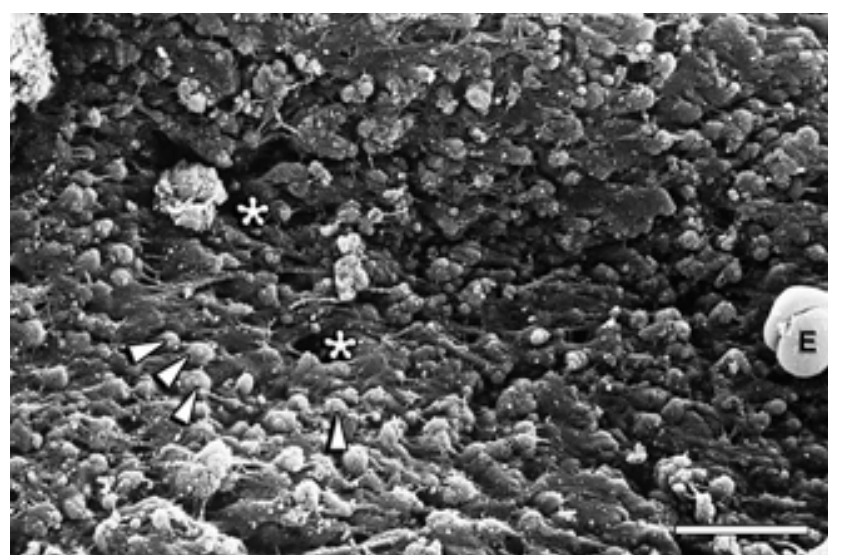

Ryc. 1. SEM. Obraz morfologiczny powierzchni błony śluzowej pokrytej biofilmem. Wycinek pobrano z okolicy lejka sitowego. W posiewie bakteryjnym wyhodowano Coagulase negativ Staphylococcus. Bar $=10$ um. Powiększenie 2000 razy

- komórki bakterii

* - kanały wodne

E - erytrocyt

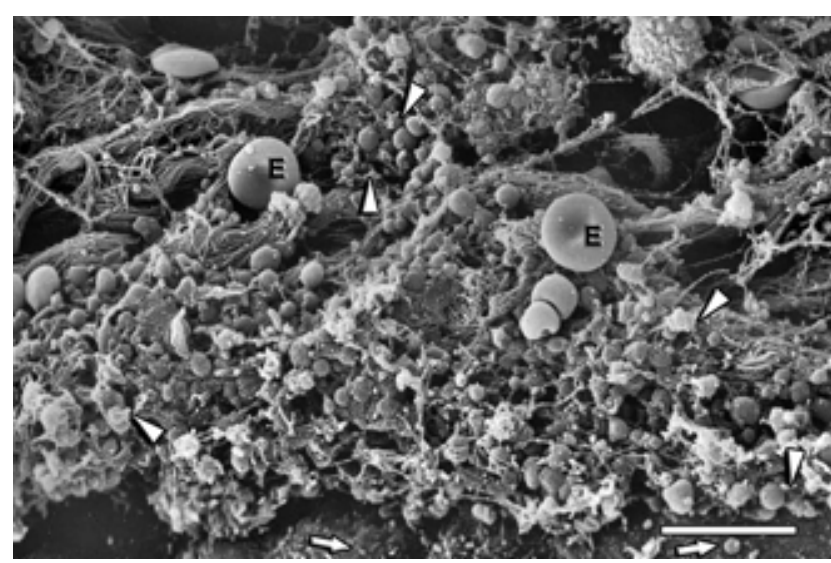

Ryc. 2. SEM. Morfologia powierzchni błony śluzowej pokrytej biofilmem pobranej z okolicy zachyłka czołowego. W posiewie bakteryjnym wyhodowano Staphylococcus aureus. Bar $=10$ um. Powiększenie 2000 razy

- mikrokolonie bakterii

E - erytrocyty

$\rightarrow-$ komórki nabłonka ze zniszczonymi rzęskami

\section{DYSKUSJA}

Wiele bakterii wolnożyjących występuje w postaci pojedynczych komórek, poruszających się swobodnie. Wielu mikrobiologów od czasów Pasteura skupiało się na badaniu właściwości kultur bakteryjnych zawieszonych w roztworach wodnych. Dopiero stosunkowo niedawno odkryto, że większość bakterii przysparzających trudności w leczeniu jest

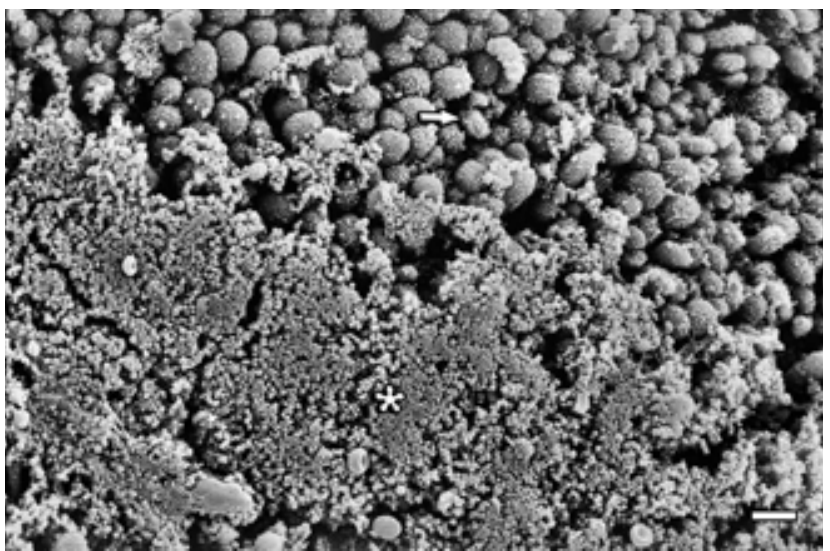

Ryc. 3. SEM. Morfologia powierzchni błony śluzowej pokrytej biofilmem pobranej z okolicy naturalnego ujścia zatoki szczękowej. W posiewie bakteryjnym wyhodowano Enterobacter species. Bar $=10$ um. Powiększenie 660 razy * - biofilm przylegający do powierzchni błony śluzowej $\rightarrow$ - komórki nabłonka ze zniszczonymi rzęskami

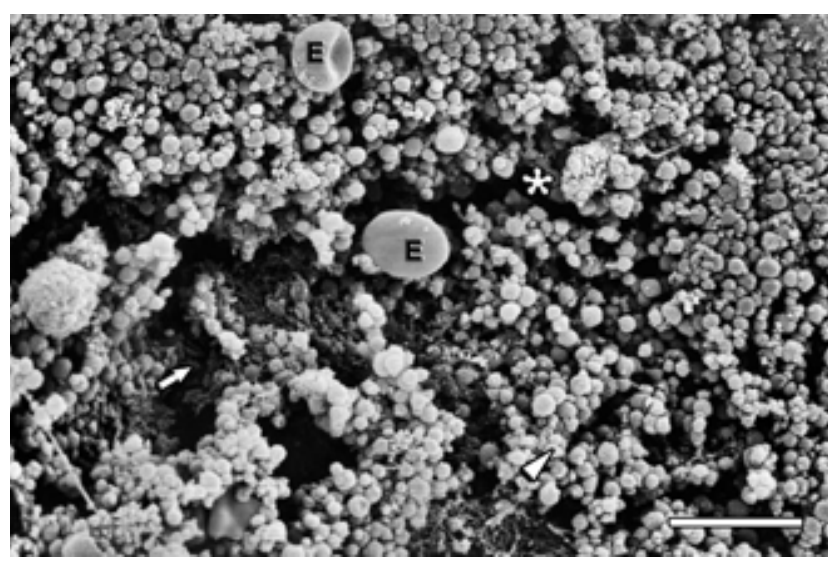

Ryc. 4. SEM. Morfologia powierzchni biofilmu. Widoczna przestrzenna struktura biofilmu. Materiał pobrano z okolicy naturalnego ujścia zatoki szczękowej. W posiewie bakteryjnym wyhodowano Enterobacter species. Bar $=10$ um. Powiększenie 2000 razy $\rightarrow-$ trójwymiarowa struktura biofilmu

* - kanaty wodne

- obfite kolonie bakterii namnażające się

w powierzchownej warstwie biofilmu

E - erytrocyt

związana z jakąś powierzchnią i żyje w biofilmie. Poznanie właściwości bakterii tworzących i żyjących w biofilmie jest bardzo istotne, gdyż tworzące go mikroorganizmy podlegają znacznym zmianom fenotypowym z chwilą związania się z powierzchnią. Zmiany te polegają na praktycznie nieustannym przekształcaniu ekspresji genów, co nadaje bakteriom zupełnie odmienne właściwości biologiczno-patogenne. 


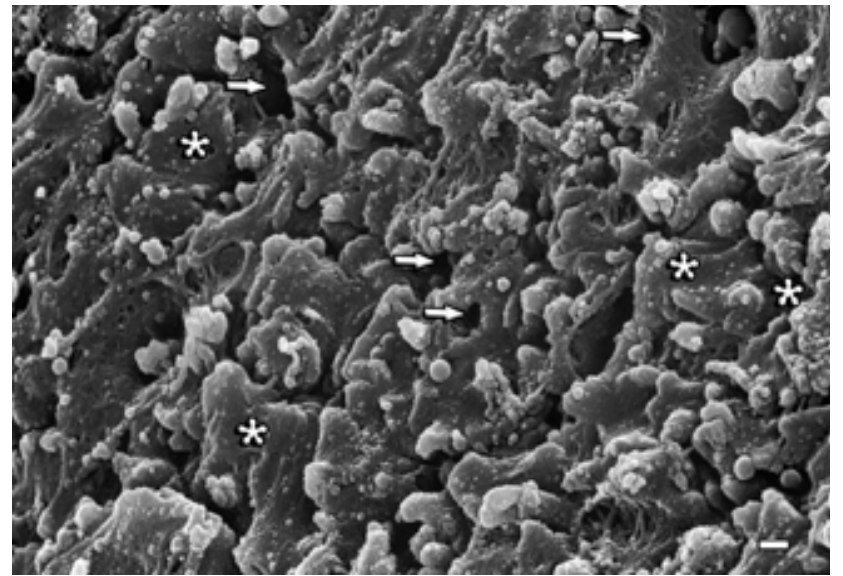

Ryc. 5. SEM. Morfologia biofilmu. Materiał pobrano z wnętrza zatoki szczękowej. W posiewie bakteryjnym wyhodowano Staphylococcus aureus. Bar $=10$ um. Powiększenie 4000 razy * - matrix biofilmu $\rightarrow-$ kanały wodne

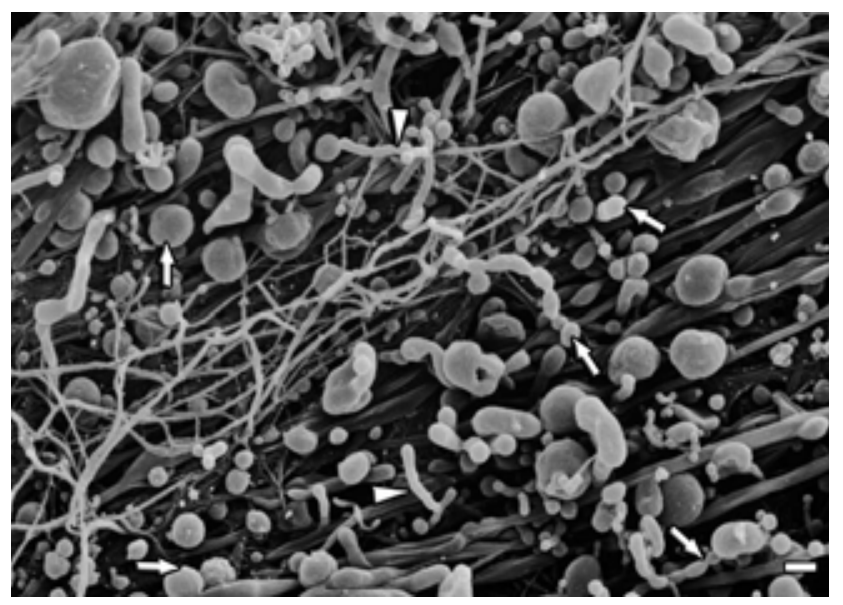

Ryc. 6. SEM. Morfologia komórek bakterii $(\rightarrow)$ oraz grzybni ( ) w formie planktonowej. Widoczne są także pojedyncze komórki drożdżaków (lewy górny narożnik zdjęcia). Brak struktury biofilmu. Materiał pobrano z wnętrza zatoki szczękowej . W posiewie bakteryjnym wyhodowano: Escherichia coli, Proteus mirabilis, Propionibacterium acnes. Bar $=1 \mathrm{um}$. Powiększenie 4000 razy

Nasze wstępne badanie 25 pacjentów z PZZP, poddanych ESS, wykazało obecność struktur biofilmów obecnych na powierzchni próbek błony śluzowej pobranych od pacjentów w czasie operacji. Należy zaznaczyć, że pacjenci kwalifikowani do operacji byli wcześniej leczeni zachowawczo z powodu PZZP bez zadowalających efektów. W 19 przypadkach za pomocą SEM stwierdzono obecność morfologicznych cech biofilmu. Natomiast w 4 przypadkach obecności biofilmu nie stwierdzono. U wszystkich pacjentów podczas operacji pobrano wymazy z wnętrza zatok celem analizy bakteriologicznej.

Obserwowano różne struktury biofilmów (ryc. 1-5), zakładając, że podstawowym parametrem rozpoznania biofilmu jest obecność kulistych i sferycznych struktur wielkości od 0,05 do 2,0 mikronów otoczonych matrix, położonych na powierzchni nabłonka rzęskowego. Wadą SEM jest brak możliwości określenia gatunku bakterii tylko na podstawie obserwacji ich cech morfologicznych powierzchni. Kolejną trudnością, raczej techniczną, było płukanie wycinków pokrytych krwią tak, aby usunąć krew nienaruszając przy tym struktury biofilmu. W obrazach SEM często obserwowano pasma włóknika na powierzchni preparatu przesłaniającego nabłonek błony śluzowej i prawdopodobnie obecny biofilm. Bardzo często obserwowano biofilm pokrywający nieprawidłowy nabłonek pozbawiony rzęsek. W 2 przypadkach, stanowiących grupę kontrolną, obserwowano nabłonek pokryty prawidłowymi rzęskami.

\section{WNIOSKI}

1. Biofilmy bakteryjne pełnią istotną rolę w patogenezie i przebiegu przewlekłego zapalenia zatok przynosowych.

2. Udowodnienie tej tezy wymaga dalszych badań z wykorzystaniem metod pozwalających nie tylko stwierdzić obecność biofilmu, ale także ocenić typy mikroorganizmów, które go tworzą.

3. W badaniu endoskopowym nie ma możliwości stwierdzenia występowania biofilmów na powierzchni błony śluzowej.

4. Badanie materiału w SEM wydaje się obecnie jedną z najczęściej stosowanych metod do stwierdzenia obecności biofilmów.

5. Występowanie biofilmów u pacjentów z PZZP może indukować współistnienie takich schorzeń, jak: polipy nosa, astma oskrzelowa, uczulenie na NLPZ.

6. W celu lepszej oceny patogennej roli biofilmów w PZZP wydają się zasadne dalsze badania przeprowadzone na większej grupie chorych oraz grupie kontrolnej.

\section{PIŚMIENNICTWO}

1. Post JC, Stoodley P, Hall-Stoodley L, Ehrlich, GD. The role of biofilms in otolaryngologic infections. Curr Opin Otolaryngol Head Neck Sur 2004; 12: 185-190.

2. Coticchia J, Zuliani G, Coleman C, Carron M, Gurrola II J, Haupert M, i wsp. Chronic Rhinosinusitis vs Obstructive Sleep Apnea Arch Otolaryngol Head Neck Surg 2007; 133: 110-114. 
3. Costerton JW, Steward PS, Greenberg EP. Bacterial biofilms: a common cause of persistent infections. Science 1999; 284, 1318-1322.

4. Donlan R. Biofilms: microbial life on surfaces. Emerg Infect Diseases 2002; 8(9): 881-890.

5. Fergie N, Bayston R, Pearson J, Birchall J. Is otitis media with effusion a biofilm infection? Clin Otolaryngol 2004; 29: 3846.

6. Harvey RJ, Lund VJ. Biofilms and chronic rhinosinusitis: systematic review of evidence, current concepts and directions for research. Rhinology 2007; 45(1): 3-13.

7. Lawrence JR, Korber DR, Hoyle BD, Costerton JW, Caldwell DE, i wsp. Optical sectioning of microbial biofilms. J Bacteriol 1991; 173: 6558-6567.

8. Costerton W, Veeh R, Shirtliff M, Pasmore M, Post C, Ehrlich G, i wsp. The application of biofilm science to the study and control of chronic bacterial infections. J Clin Invest 2003; 112: 1466-1477.

9. Sanglard D. Resistance of human fungal pathogens to antifungal drugs. Curr Opin Microbiol 2002; 5: 379-385.

10. Hall-Stoodley L, Costerton JW, Stoodley P. Bacterial biofilms: from the natural environment to infectious diseases. Nat Rev Microbiol 2004; 2: 95-108.

11. Palmer JN, Górski NP. Biofilmy bakteryjne w przewlekym zapaleniu zatok przynosowych. Magazyn Otorynolaryngologiczny suplement 2006 Czerwiec tom: IX
12. Brown MRW, Allison DG, Gilbert P. Resistence of bacterial biofilms to antibiotics: A growth-rare related effect? J Antimicrob Chemother 1988; 22: 777-780.

13. Sanclement JA, Webster P, Thomas J., Ramadan HH. Bacterial biofilms in surgical specimens of patients with chronic rhinosinusitis. Laryngoscope. 2005;115(4): 578-582.

14. Bagge N, Hentzer M, Andersen JB, Ciofu O, Givskov M, Hoiby N. Dynamics and spatial distribution of beta-lactamase expression in Pseudomonas aeruginosa biofilms. Antimicrob Agents Chemother 2004; 48: 1168-1174.

15. Walters MC, 3rd, Roe F, Bugnicourt A, Franklin MJ, Stewart PS. Contributions of antibiotic penetration, oxygen limitation, and low metabolic activity to tolerance of Pseudomonas aeruginosa biofilms to ciprofloxacin and tobramycin. Antimicrob Agents Chemother 2003; 47: 317-323.

Adres autora:

Roman Głowacki

Katedra i Klinika Otolaryngologii

ul. Śniadeckich 2

31-502 Kraków

Pracę nadesłano: 18.03.2008 r. 